\title{
Detection of allele and genotype frequencies of bovine leukocyte adhesion deficiency, factor XI deficiency and complex vertebral malformation disease genes in Holstein cattle
}

\author{
Neziha HACIHASANOĞLU ÇAKMAK ${ }^{1 \mathrm{a} \bowtie}$, Hasret YARDİBí ${ }^{2 b}$ \\ ${ }^{1}$ İstanbul Medipol University, Vocational School of Health Services, Pharmacy Services; ${ }^{2}$ İstanbul University, Faculty of Veterinary \\ Medicine, Department of Biochemistry, İstanbul, Turkey. \\ ${ }^{\mathrm{a} O R C I D ~ I D: ~ 0000-0002-6183-5015 ; ~ ' ~} \mathrm{~b}$ ORID ID: 0000-0002-2779-1098 \\ ${ }^{凶}$ Corresponding author: ncakmak@ medipol.edu.tr
Received date: 25.06 .2018 - Accepted date: 01.05 .2019
}

\begin{abstract}
Hereditary diseases cause yield and economic loses. It is important to examine hereditary diseases at the molecular level and to remove diseases from the herd. In our study, it was aimed to determine allele frequencies of genes that cause bovine leukocyte adhesion deficiency, factor XI deficiency and complex vertebral malformation diseases in Holstein cattle. Blood samples were randomly taken from 300 Holstein cattle in different dairy farms in Kocaeli, Sakarya and Balıkesir provinces. Deoxyribonucleic acid samples were isolated from blood samples by using the standard ammonium acetate salt-out method. The target regions were amplified by polymerase chain reaction to determine the mutant alleles causing bovine leukocyte adhesion deficiency, factor XI deficiency and complex vertebral malformation. According to the nucleotide chromotograms of the samples subjected to bovine leukocyte adhesion deficiency analysis, it was determined that 4 out of 300 cattle were heterozygous and 296 were homozygous. Polymerase chain reaction procedure for factor XI deficiency disease was sufficient, while samples amplified by polymerase chain reaction for complex vertebral malformation disease were subjected to restriction particle length polymorphism. Factor XI deficiency and complex vertebral malformation disease genes were all homozygous normal.

Keywords: Anaemia, $\beta 2$ integrin glycoprotein, Holstein, point mutation, PCR-RFLP, SLC35A3.
\end{abstract}

\section{Holştayn ırkı sığırlarda sığır lökosit bağlanma yetmezliği, faktör XI eksikliği ve kompleks vertebral malformasyon hastalıkları genlerinin allel ve genotip sıklıklarının tespit edilmesi}

Özet: Kalıtsal hastalıklar verim ve ekonomik kayıplara neden olur. Kalıtsal hastalıkları moleküler düzeyde incelemek, hastalıkları sürüden uzaklaştırmak için önemlidir. Araştırmamızda, Holstayn ırkı sığırlarda sığır lökosit bağlanma yetmezliği, faktör XI eksikliği ve kompleks vertebral malformasyon hastalıklarına sebep olan genlerin allel sıklıklarının tespit edilmesi amaçlanmıştır. Kocaeli, Sakarya ve Balıkesir illerinde bulunan farklı çiftliklerdeki 300 adet Holştayn sığırdan kan örnekleri alınmıştır. Kan örneklerinden standart amonyum asetat çöktürme yöntemiyle deoksiribonükleik asit örnekleri izole edilmiştir. Sığır lökosit bağlanma yetmezliği, faktör XI eksikliği ve kompleks vertebral malformasyona sebep olan mutant allelleri belirlemek için hedef bölgeler polimeraz zincir reaksiyonu ile çoğaltılmıştır. Sığır lökosit bağlanma yetmezliği için dizin analizi işlemine tabi tutulan örneklerin nükleotid kromotogramlarına göre toplamda 300 adet sığırdan 4 tanesi heterozigot birey, 296 tanesinin homozigot birey olduğu tespit edilmiştir. Faktör XI eksikliği hastalığı için polimeraz zincir reaksiyonu işlemi yeterli olup, kompleks vertebral malformasyon hastalığı için ise polimeraz zincir reaksiyonu ile çoğaltılan örnekler restriksiyon parçacık uzunluğu polimorfizmi işlemine tabi tutulmuştur. Faktör XI eksikliği ve kompleks vertebral malformasyon hastalıkları genlerinin hepsi homozigot normal bulunmuştur.

Anahtar sözcükler: Anemi, $\beta 2$ integrin glikoprotein, Holştayn, nokta mutasyonu, PCR-RFLP, SLC35A3.

About $70 \%$ of the cows utilized for the milk industry in the world are artificially inseminated (9). The artificial insemination method increases the yield per animal, while at the same time raising genetic similarity in breeds (28). Increasing genetic similarity within the breed has been shown to cause the spread of hereditary diseases, which rapidly reduces fertility in the population. It has been reported that these hereditary diseases tend to spread to the whole world in a very short time, even continents (23). For this reason, it is emphasized that the mutant alleles that 
cause hereditary diseases can be cleared from the population only by determining the carrier individuals and removing them from the herd (1). It is stated that about 300 hereditary diseases have been detected in cattle breeds which have been extensively bred in the last fifty years (2).

Insufficiency of bovine leukocyte binding; was detected in the Holstein cattle. It can cause death due to the mucosal infections that appear at birth. Bovine leukocyte adhesion deficiency (BLAD) is a hereditary disease that is characterized by autosomal recessive inheritance $(1,7)$. Bovine leukocyte binding deficiency disease is a point mutation that causes the substitution of the adenine nucleotide with the guanine nucleotide at position 383 of the gene that encodes the $\beta 2$ integrin (CD18) glycoprotein, the subunit of the CD11/CD18 complex, which provides endothelial-leukocyte binding. The disease was reported in Turkey in 2004 (4). Factor XI, one of the proteins involved in blood coagulation, is also called serine protease (11). It has been determined that the disease results in a mutation that causes 76 bases to be added to exon 12 of factor XI gene (23). In cattle, this hereditary disease was first identified in US Holsteins in 1969. The mutant alleles causing factor XI deficiency (FXID) in Holsteins bred in Turkey were first reported in 2009 (19). There are several symptoms such as prolonged bleeding time after injection, bloody milk intake and anaemia $(9,18)$. In addition to these symptoms, calves show a lower birth weight and survival rate than the norm. It has been stated that the probability for affected animals to catch infectious diseases is higher than that of normal calves (18). FXID has reduced clotting activity in heterozygous individuals, causing it to completely disappear in homozygotes (19). Holstein cattle, a mutation is formed in the SLC35A3 gene that encodes the uridine diphosphate-N-acetylglucosamine transporter. Point mutation results the disease that causes the guanine nucleotide at position 559 of the SLC35A3 gene to change places with thymine (2). Complex vertebral malformation $(\mathrm{CVM})$ is a lethal disease characterized by autosomal recessive inheritance in Holstein cattle. Approximately $80 \%$ of fetuses that are homozygous with the mutant alleles are discarded before the 260th day of gestation (3). The offspring that do complete the normal gestational period is mostly stillborn. Symptomatic joint curvatures, spinal cord curvature, malformations in the vertebral column, multiple spinal anatomical defects in the neck and back vertebrae of the spinal column extending from the skull to the tail spin, and adhesion in the vertebrae are characteristics of shortened neck and thoracic vertebrae in offspring that are not discarded $(2,3,8)$. This is the most important of the clinical signs and the lethal shortness of the spine for the embryo (2). Holsteins are one of the most preferred cattle breeds around the world, also in Turkey. Autosomal genetic diseases are an important issue for dairy cattle owners. It is necessary to investigate the genetic structures of cattle in Turkey in terms of hereditary disorders. Due to the inadequacy of native gene resources, the genetic structures of many hereditary diseases thought to be unique to the race have not been fully brought to light. The main objective of this study was to identify hereditary disease carrier BLAD, FXID and CVM in Kocaeli, Sakarya and Balıkesir's dairy cattle population. The results of our study will be a resource for future studies.

This study was approved by the Local Ethics Committee on Animal Experiments of Istanbul University (Approval no: 09.09.2013/103). For the study, blood samples were collected randomly from 300 Holstein cattle in Kocaeli (Kandıra: Elite Agriculture and Livestock Milk Production Center (54 cattle), Aygaz (21 cattle), Asım Ağa Farm (25 cattle), Sakarya (Karapüçek town Ali Rıza Yıldız (20 cattle), İsmet Yıldız (19 cattle), İbrahim Kulaç (18 cattle), Yıldırım Özcan (17 cattle), Tacit Şahin (12 cattle), Hasan Burnaz (9 cattle), Aydın Özcan (5 cattle) and Balıkesir (Okyanus Farm, 100 cattle) provinces. Samples were taken from the tail vein, collected in vacuum tubes containing ethylene diamine tetra acetic acid (EDTA) and stored at $-20^{\circ} \mathrm{C}$. Genomic deoxyribonucleic acid-(DNA) samples were isolated using the standard salt-out method (21). The Polymerase Chain Reaction (PCR) mixture volume of $25 \mu$ l contained the following: $1 \mathrm{U}$ Taq deoxyribonucleic acid polymerase (Fermantas Life Sci., Canada), 2- $2.5 \mathrm{ml}$ 10X PCR buffer, $1.5 \mathrm{mM} \mathrm{MgCl}$, 50-100 ng DNA, $100 \mathrm{mM}$ (dNTPs) (Fermantas Life Sci., Canada), and 10 pmol of each primer for all of the fragments. Designed primers (20), were used to reproduce the mutated region of BLAD; the order of primers was as follows: F: 5'GAATAGGCATCCT GCATCATATCCACCA3', R:5'CTTGGGGTTTCAGG GGAAGATGGAGTAG3'. Amplification consisted of, an initial denaturation $94^{\circ} \mathrm{C}$ for $5 \mathrm{~min}$, followed by 35 cycles of $94^{\circ} \mathrm{C}$ for $1 \mathrm{~min}$, annealing at $61^{\circ} \mathrm{C}$ for $1 \mathrm{~min}$ and extension at $72^{\circ} \mathrm{C}$ for $1 \mathrm{~min}$, with a final extension of $72^{\circ} \mathrm{C}$ for 10 minutes. Designed primers (31), were used to reproduce the mutated region of FXID; the order of primers was as follows: F: 5'CCCACTGGCTAGGA ATCGTT3', R: 5'CAAGGCAATGTCATATCCAC3'. Amplification consisted of an, initial denaturation $94^{\circ} \mathrm{C}$ for $5 \mathrm{~min}$, followed by 35 cycles of $94^{\circ} \mathrm{C}$ for $1 \mathrm{~min}$, annealing at $54^{\circ} \mathrm{C}$ for $1 \mathrm{~min}$ and extension at $72^{\circ} \mathrm{C}$ for $1 \mathrm{~min}$, with a final extension of $72^{\circ} \mathrm{C}$ for 10 minutes. Designed primers (17), were used to reproduce the mutated region of CVM: the order of primers was as follows: F: 5'CACA ATTTGTAGGTCTCACTGCA3', R: 5'CGATGAAAAA GGAACCAAAAGGG3'. Amplification consisted of an, initial denaturation $96^{\circ} \mathrm{C}$ for 5 min, followed by 30 cycles of $95^{\circ} \mathrm{C}$ for $30 \mathrm{sec}$, annealing at $56^{\circ} \mathrm{C}$ for $1 \mathrm{~min}$ and extension at $72^{\circ} \mathrm{C}$ for $30 \mathrm{sec}$, with a final extension of $72^{\circ} \mathrm{C}$ 
for 10 minutes. PCR products were visualized after electrophoresis on a $2 \%$ agarose gel with a longwavelength UV transilluminator (Thermo Fisher Scientific, Germany). Genotyping for CVM was done using PCRRFLP methods. The PCR products were digested with the following fast digest restriction endonuclease: Eco T22 I (Ava III) for CVM disease. For RFLP analysis, $10 \mathrm{ml}$ of the PCR products were digested for 60 minutes with 10 units of restriction enzyme at $37^{\circ} \mathrm{C}$. The digested DNA fragments were separated by electrophoresis in $2 \%$ agarose gel. BLAD genotypes were identified by DNA sequencing. In our study, the sequence analysis process was carried out by Refgen-Gene Research and Biotechnology Ltd. Sti. (Gölbaşı-Ankara). Sequencing was performed by using an ABI-3100 sequencer (PE Biosystems) and the BiyDye $\mathrm{Tm}$ terminator cycle sequencing kit after the purification of the PCR products. The forward primer was used to sequence the PCR products of BLAD. The genotypes of FXID were detected by PCR methods. Genotype and allele frequencies of each genetic disease were calculated using the PopGene 32 software program and chi-square tests $\left(x^{2}\right)$ were also used to check whether the populations were in Hardy-Weinberg equilibrium using PopGene 32 software (32).

PCR amplification for BLAD, FXID and CVM was successful in all 300 samples that were analyzed. BLAD genotypes were identified by DNA sequencing. After sequencing, 4 BLAD carriers were found. The distributions of the CD18 protein allele and genotype frequency in Holstein cattle are shown in the Table 1. After the PCR, the normal FXID allele in unaffected animals produced a single $244 \mathrm{bp}$ fragment. In homozygous affected animals, the fragment had a length of $320 \mathrm{bp}$ and FXID carriers exhibited two fragments of $244 \mathrm{bp}$ and $320 \mathrm{bp}$. The PCR products of CVM was digested with Eco T22 I (Ava III). After digestion, the normal CVM allele in unaffected cattle produced a single fragment of $233 \mathrm{bp}$. CVM carriers exhibit three fragments of $233 \mathrm{bp}, 212 \mathrm{bp}$ and $21 \mathrm{bp}$. Among the 300 Holstein cattle reared in Kocaeli, Sakarya and Balıkesir provinces 4 BLAD carriers found only, while carriers of FXID and CVM were not detected.

The incidence of BLAD carriers was found to be $1.37 \%$ in China (33), 6.6\% in Iran (14), 5\% (24) and
$1.69 \%$ (25) in India. In Turkey, Şahin et al. (27) and Korkmaz Ağaoğlu et al. (16) reported the prevelance of BLAD carriers in Holsteins to be $2.18 \%, 2 \%$ respectively. In our study, the incidence of BLAD carriers among the Holstein cattle was estimated at $1.33 \%$. According to the results we have obtained, our incidence is found to be lower than those reported in studies from China, India, Iran and Turkey. If we consider that there are more than 300 Holstein cattle in Kocaeli, Sakarya and Balıkesir provinces, the change of the incidence by increasing the number of animals in the study is possible.

According to the statistical result made, the number of individuals expected to be carriers in the future was calculated as 3.98. A change that would express a statistical significance of this ratio in the future is not expected and shows the distribution in accordance to the Hardy-Weinberg equilibrium and has not statistical significance. However, the removal of carrier individuals from the herd is of great importance in terms of preventing the emergence of sick individuals in the future. Carrier individuals must not be used in selection works. If the individuals are male, the sperm must not be used and if female, they must not be impregnated. Furthermore, these animals must be sent for slaughter in order to keep them away from the herd. There are some factors affecting diseases that occur in a region. Most significant are factors such as the effect of regional sperm export in the last 10 years, the frequency of use of this sperm in insemination, whether or not animals with genetic defects have been introduced, and whether or not artificial insemination or a stud bull was used in impregnation.

Previously, carriers of FXID have been identified in Turkish Holstein cattle $(5,15)$. The frequency of mutant FXID allele was estimated to be $1.69 \%$ (5) and $0.4 \%$ (15), similar to that the frequency reported by Mondal et al. $1.69 \%$ (22). Similarly, the percentage of carrier cattle was found to be $0.67 \%$ (31) and $1.8 \%$ (16). The prevalance of carriers found in this study was $0 \%$, similar to previous studies $(6,10)$. The frequency in our study was found to be low compared to other studies. The low frequency is similar to results from studies in Iran, and this situation may be due to the fact that the embargo applied to Iran inhibited animal transportation.

Table 1 Detection of allele and genotype frequency of BLAD. Tablo 1 BLAD'ın alel ve genotip sıklığının tespiti.

\begin{tabular}{|c|c|c|c|c|c|c|c|c|}
\hline \multirow[b]{3}{*}{ Breed } & \multirow[b]{3}{*}{$\mathrm{n}^{1}$} & \multicolumn{4}{|c|}{ Genotype } & \multicolumn{2}{|c|}{ Allele frequency $(\%)$} & \\
\hline & & \multicolumn{2}{|c|}{$\mathbf{A A}$} & \multicolumn{2}{|c|}{ AG } & \multirow[t]{2}{*}{ A } & \multirow[t]{2}{*}{ G } & \\
\hline & & Obs. $^{2}$ & Exp. $^{3}$ & Obs. $^{2}$ & Exp. $^{3}$ & & & $\left(x^{2}\right)^{4}$ \\
\hline Holstein & 300 & 296 & 296.01 & 4 & 3.980 & 0.9933 & 0.0067 & $0.0101 \mathrm{NS}$ \\
\hline
\end{tabular}

${ }^{1}$ Number of the Holstein cattle, ${ }^{2}$ Observed of values, ${ }^{3}$ Expected of values, ${ }^{4}$ Hardy-Weinberg equilibrium, NS: Not significant 
The absence of animal transportation may prevent the same bulls from being used in artificial insemination, and the absence of the disease-causing genome in these bulls may prevent the disease from appearing in other animals.

Twenty-six and thirty-four CVM carriers were identified, corresponding to the heterozygote carrier frequency of $21.6 \%$ (26) and 34\% (14) respectively in Iran, and no mutant homozygote was found. In China, it has been reported that the frequency of the carrier animals are $10.48 \%$ (33), $2.92 \%$ (29) and $15.58 \%$ (30) in Holstein cattle. In our country, Kulaklı and Akyüz (17) did not find carriers of CVM. In our study, we did not find any carriers of CVM. Increasing the number of animals we use in our study may cause a change in the frequency of this disease. The prevention of genetic variations in species used for breeding farm animals has played a role in reducing economic losses. Studies carried out in the field of molecular genetics are useful in reducing anomalies that may occur at birth or in periods later in life (1). The importance of heterozygous animals can be easily understood considering the fact that many hereditary diseases follow recessive inheritance (12). Heterozygous animals can survive for many years without showing any symptoms. Therefore they need to be removed from the herd (13).

In our study, 300 Holstein cattle raised in the provinces of Kocaeli, Sakarya, and Ballkesir were examined and 4 BLAD disease carriers were found, while no carriers of the FXID or CVM diseases were found. In our study, the aim was to investigate mutant alleles causing BLAD, FXID and CVM diseases in Holstein cattle in Turkey, so as to screen candidate breeders for these diseases, and determine a feasible method to do so in the future. Given the size of the Holstein population in Turkey, the probability of having more individuals with BLAD, FXID, and CVM diseases arise. Therefore, the number of studies that screen candidate Holstein breeders in different regions of Turkey must be increased.

\section{Acknowledgement}

This study was supported by the Istanbul University BAP Project Application (Project number: 38954). This study was produced from a $\mathrm{PhD}$ thesis. We wish to thank the cattle Breeders of Kocaeli, Sakarya and Balıkesir.

\section{References}

1. Ackermann MR, Kehrli ME, Morfitt DC (1993): Ventral dermatitis and vasculitis in a calf with bovine leukocyte adhesion deficiency. J Am Vet Med Assoc, 202, 413-415.

2. Agerholm S, Bendixen C, Andersen O, et al. (2001): Complex vertebral malformation in Holstein calves. J Vet Diagn Invest, 13, 283-289.
3. Agerholm JS, Andersen O, Almskou MB, et al. (2004): Evaluation of the inheritance of the complex vertebral malformation syndrome by breeding studies. Acta Vet Scand, 45, 133-137.

4. Akyüz B (2004) Türkiye'deki Holştayn sı̆̆ırlarında sığır lökosit bağlanma yetmezliğinin (bovineleukocyte adhesion deficiency, BLAD) restriksiyon parçacık uzunluk polimorfizmi (restriction fragment length polymorphism, RFLP) ile belirlenmesi. Doktora Tezi. Ankara Üniversitesi Sağlık Bilimleri Enstitüsü, Zootekni Programı. Ankara.

5. Akyüz B (2013): Türkiye'deki iki farklı işletmede yetiştirilen Holştayn boğalarda faktör XI yetmezliği (FXID) allel frekansinın belirlenmesi. Kafkas Üniv Vet Fak Derg, 19(1), 127-131.

6. Bagheri S, Amirinia C, Chamani M, et al. (2012): Identification of factor XI deficiency in Khuzestan Buffalo population of Iran. Global Vet, 8(6), 598-600.

7. Batt CA, Wagner P, Wiedmann M, et al. (1994): Detection of bovine leukocyte adhesion deficiency by nonisotopic ligase chain peaction. Anim Genet, 25, 95-98.

8. Chu Q, Sun D, Yu Y, et al. (2008): Identification of complex vertebral malformation carriers in Chinese Holstein. J Vet Diagn Invest, 20, 228-230.

9. Citek J, Rehout V, Hajkova J, et al. (2006): Monitoring of the genetic health of cattle in the Czech Republic. Vet Med Czech Rep, 51(6), 333-339.

10. Eydivandi C, Amirinia C, Jamah-Kasha NE, et al. (2011): Study of factor XI deficiency in Khuzestan cattle population of Iran. African J Biotechnol, 10(4), 718-721.

11. Ghanem ME, Nishibori M, Nakao T, et al. (2005): Factor $X I$ mutation in a Holstein cow with repeat breeding in Japan. J Vet Med Sci, 67(7), 713-715.

12. Ghanem ME, Nakao T, Nishibori M (2006): Deficiency of uridine monophosphate syntheses (DUMPS) and $X$ chromosome deletion in fetal mummification in cattle. Anim Rep Sci, 91, 45-54.

13. Ghanem ME, Akita M, Suzuki T, et al. (2008): Complex vertebral malformation in Holstein cows in Japan and its inheritance to crossbred F1 generation. Anim Rep Sci, 103, 348-354.

14. Hemati B, Gharaie-Fathabad S, Fazeli MH, et al. (2015): Investigation of bovine leukocyte adhesion deficiency (BLAD) and complex vertebral malformation (CVM) in a population of Iranian Holstein cows. Iranian J Appl Anim Sci, 5(1), 69-72.

15. Karsli T, Şahin E, Argun Karsli B, et al. (2011): Identification of alleles for faktör XI (FXID) and uridine monophosphate sythase (DUMPS) deficiencies in Holstein cows reared in Antalya. Kafkas Üniv Vet Fak Derg, 17(3), 503-505.

16. Korkmaz Agaoğlu Ö, Agaoğlu AR, Saatcı M (2015): Estimating allele frequencies of some hereditary diseases in Holstein cattle reared in Burdur province, Turkey. Turkish J Vet Anim Sci, 39, 338-342.

17. Kulakli GN, Akyüz B (2011): Kayseri bölgesinde yetiştirilen Holştayn sığırlarında kompleks vertebral malformasyon hastallğ geninin allel frekanslarının belirlenmesi. Erciyes Üniv Vet Fak Derg, 8(2), 69-74.

18. Marron BM, Robinson JL, Gentry PA, et al. (2004): Identification of a mutation associated with factor XI deficiency in Holstein cattle. Anim Genet, 35(6), 454-456. 
19. Meydan H, Yildiz MA, Ozdil F, et al. (2009): Identification of factor XI deficiency in Holstein cattle in Turkey. Acta Vet Scand 51, 5, 2009.

20. Meydan H, Yildiz MA, Agerholm JS (2010): Screening for bovine leukocyte adhesion deficiency, deficiency of uridine monophosphate synthase, complex vertebral malformation, bovine citrullinaemia, and factor XI deficiency in Holstein cows reared in Turkey. Acta Vet Scand, 52, 56.

21. Miller M, Dykes DD, Polesky HF (1985): A simple salting out procedure for extracting DNA from human nucleated cells. Nucleic Acid Res, 16, 1215-1219.

22. Mondal K, Chakravarti S, Ghosh AK, et al. (2016): Novel identification of factor XI deficiency in Indian Sahiwal (Bos indicus) cattle. Mol Biol Rep 43, 213-219.

23. Mukhopadhyaya PN, Jha M, Muraleedharan P, et al. (2006): Simulation of the normal, carrier and affected controls for large-scale genotyping of cattle for factor XI deficiency. Genet Mol Res 5(2), 323-332.

24. Patel M, Patel RK, Singh KM, et al. (2011): Detection of genetic polymorphism in CD18 gene in cattle by PCRRFLP. Woyamba J Anim Sci, 578, 110-111.

25. Roy A, Kotikalapudu R, Patel RK, et al. (2012): New cases of bovine leukocyte adhesion deficiency (BLAD) carriers in Indian Holstein cattle. Int J Vet Sci, 1(2), 80-82.

26. Saberi J, Hemati B, Noshary A (2014): Studying the genetic defects of CVM in Holstein cows of Alborz province. Bullet Env Pharma Life Sci, 3(12), 38-41.
27. Şahin E, Karslı T, Galiç A, et al. (2013): Identification of bovine leukocyte adhesion deficiency (BLAD) and bovine citrullinaemia $(B C)$ alleles in Holstein cows reared in Antalya region. J Appl Anim Res, 41(1), 56-60.

28. Thomsen B, Horn P, Panitz F, et al. (2006): A missence mutation in the bovine SLC35A3 gene, encoding a UDP-Nacetylglucosamine transporter causes complex vertebral malformation. Genom Res, 16, 97-105.

29. Wang C, Tong Q, Hu XZ, et al. (2011): Identification of complex vertebral malformation carriers in Holstein cattle in South China. Genet Mol Res, 10(4), 2443-2448.

30. Wang S, Hao H, Zhao X, et al. (2012): A rapid mismatch polymerase chain reaction assay to detect carriers of complex vertebral malformation in Holstein cattle. J Vet Diagn Invest, 24(3), 568-571.

31. Yaşar G, Akyüz B (2012): Kayseri civarında yetiştirilen Holştayn ineklerde kalitsal Faktör XI yetmezliği geninin allel frekanslarinın belirlenmesi. Erciyes Üniv Vet Fak Derg, 9(1), 7-12.

32. Yeh F, Yang RC, Boyle T (2000): Popgene (v.1.32) Microsoft Windows-based freeware for Population Genetic Analysis. Retrieved from http://www.ualberta.ca/ fyeh/popgene.

33. Zhang Y, Fan X, Sun D, et al. (2012): A novel method for rapid and reliable detection of complex vertebral malformation and bovine leukocyte adhesion deficiency in Holstein cattle. J Anim Sci Biotechnol, 3, 24. 